\title{
Neurturin Overexpression in Skin Enhances Expression of TRPM8 in Cutaneous Sensory Neurons and Leads to Behavioral Sensitivity to Cool and Menthol
}

\author{
Ting Wang, ${ }^{1,2,3 *}$ Xiaotang Jing, ${ }^{1,2,3 *}$ Jennifer J. DeBerry, ${ }^{1,2,3}$ Erica S. Schwartz, ${ }^{3}$ Derek C. Molliver, ${ }^{1,2,3}$ \\ Kathryn M. Albers, ${ }^{1,2,3}$ and Brian M. Davis ${ }^{1,2,3}$ \\ ${ }^{1}$ University of Pittsburgh School of Medicine, Department of Medicine, Division of Gastroenterology, Hepatology and Nutrition, ${ }^{2}$ Center for Neuroscience at \\ the University of Pittsburgh, and ${ }^{3}$ Pittsburgh Center for Pain Research, Pittsburgh, Pennsylvania 15261
}

\begin{abstract}
Neurturin (NRTN) is a member of the glial cell line-derived neurotrophic factor family of ligands that exerts its actions via Ret tyrosine kinase and GFR $\alpha 2$. Expression of the Ret-GFR $\alpha 2$ coreceptor complex is primarily restricted to the peripheral nervous system and is selectively expressed by sensory neurons that bind the isolectin $\mathrm{B}_{4}\left(\mathrm{IB}_{4}\right)$. To determine how target-derived NRTN affects sensory neuron properties, transgenic mice that overexpress NRTN in keratinocytes (NRTN-OE mice) were analyzed. Overexpression of NRTN increased the density of PGP9.5-positive, but not calcitonin gene-related peptide-positive, free nerve endings in footpad epidermis. GFR $\alpha 2$ immunopositive somata were hypertrophied in NRTN-OE mice. Electron microscopic analysis further revealed hypertrophy of unmyelinated sensory axons and a subset of myelinated axons. Overexpression of NRTN increased the relative level of mRNAs encoding GFR $\alpha 2$ and Ret, the ATP receptor $\mathrm{P}_{2} \mathrm{X}_{3}$ (found in $\mathrm{IB}_{4}$-positive, GFR $\alpha 2$-expressing sensory neurons), the acid-sensing ion channel $2 \mathrm{a}$, and transient receptor potential cation channel subfamily member M8 (TRPM8) in sensory ganglia. Behavioral testing of NRTN-OE mice revealed an increased sensitivity to mechanical stimuli in glabrous skin of the hindpaw. NRTN-OE mice also displayed increased behavioral sensitivity to cool temperature $\left(17^{\circ} \mathrm{C}-20^{\circ} \mathrm{C}\right)$ and oral sensitivity to menthol. The increase in cool and menthol sensitivity correlated with a significant increase in TRPM8 expression and the percentage of menthol-responsive cutaneous sensory neurons. These data indicate that the expression level of NRTN in the skin modulates gene expression in cutaneous sensory afferents and behavioral sensitivity to thermal, chemical, and mechanical stimuli.
\end{abstract}

\section{Introduction}

Neurotrophic growth factors are important for the maintenance of sensory neuron phenotype and functional properties in adult animals (Korsching, 1993; Lewin and Barde, 1996; McAllister et al., 1999). Neurturin (NRTN), a member of the glial cell linederived neurotrophic factor (GDNF) ligand family, is a growth factor ligand that binds a receptor complex comprised of the receptor tyrosine kinase Ret and the glycophosphatidylinositolanchored protein GFR $\alpha 2$ (Kotzbauer et al., 1996). Electrophysiologic evidence indicates that the majority of sensory neurons expressing GFR $\alpha 2$ in adult animals are polymodal nociceptors

Received Aug. 21, 2012; revised Nov. 14, 2012; accepted Dec. 4, 2012.

Author contributions: T.W., X.J., J.J.D., E.S.S., D.C.M., K.M.A., and B.M.D. designed research; T.W., X.J., J.J.D., E.S.S., D.C.M., K.M.A., and B.M.D. performed research; T.W., X.J., J.J.D., E.S.S., D.C.M., and K.M.A. analyzed data; T.W., X.J., J.J.D., E.S.S., D.C.M., K.M.A., and B.M.D. wrote the paper.

This work was supported by NIH Grants NS31826 (B.M.D.), DK063922 (E.S.S.), NS056122 (D.C.M.), and NS0330730 (K.M.A.). We thank Christopher Sullivan, Pamela Cornuet, and Charlotte Diges for excellent technical support; Mary Gail Engle (University of Kentucky, Electron Microscopy and Imaging Facility) for superb electron microscopic images that were used in this report; and Eloise Peet for help with the behavioral studies that were conducted in the Rodent Behavior Analysis Core of the University of Pittsburgh Schools of Health Sciences.

The authors declare no competing financial interests.

*T.W. and X.J. contributed equally to this work.

Correspondence should be addressed to Dr. Brian M. Davis, University of Pittsburgh, Department of Medicine, Biomedical Science Tower, Room E1457, 200 Lothrop Street, Pittsburgh, PA 15216. E-mail: bmd1@pitt.edu.

DOI:10.1523/JNEUROSCI.4012-12.2013

Copyright $\odot 2013$ the authors $\quad 0270-6474 / 13 / 332060-11 \$ 15.00 / 0$ with small somata and unmyelinated axons that bind $\mathrm{IB}_{4}$, project to skin, and transduce noxious thermal, mechanical, and chemical stimuli (Lu et al., 2001; Woodbury et al., 2004; Lindfors et al., 2006; Jankowski et al., 2009).

NRTN is required for the development and maintenance of GFR $\alpha 2$-positive sensory neurons, as indicated by a significant decrease in the number of these neurons in trigeminal (TG) and dorsal root (DRG) ganglia of NRTN knock-out (KO) mice (Heuckeroth et al., 1999). The remaining GFR $\alpha 2$-expressing neurons in these animals show significant somatic atrophy accompanied by a reduction in axon diameter in the saphenous nerve (Heuckeroth et al., 1999). Interestingly, the reduction in GFR $\alpha 2$-positive neurons in NRTN KO mice does not appear to be the result of neuron death because GFR $\alpha 2 \mathrm{KO}$ mice have a normal number of sensory neuron somata and saphenous nerve axons (Stucky et al., 2002; Lindfors et al., 2006). Consistent with studies of NRTN KO mice, examination of GFR $\alpha 2 \mathrm{KO}$ mice revealed that the size of $\mathrm{IB}_{4}$-binding neurons in the DRG and the density of unmyelinated free nerve endings (as visualized with PGP9.5 staining) in the footpad skin were markedly reduced (Lindfors et al., 2006).

NRTN/GFR $\alpha 2$ signaling appears to regulate functional properties of peripheral nociceptors. Electrophysiological analysis of dissociated DRG neurons from GFR $\alpha 2$ KO mice showed that NRTN/GFR $\alpha 2$ signaling is required for transduction of noxious heat but not mechanical stimuli in $\mathrm{IB}_{4}$-binding nociceptors 
A

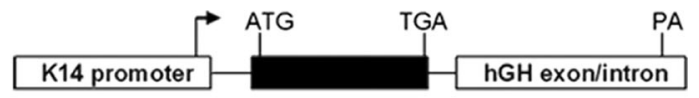

B

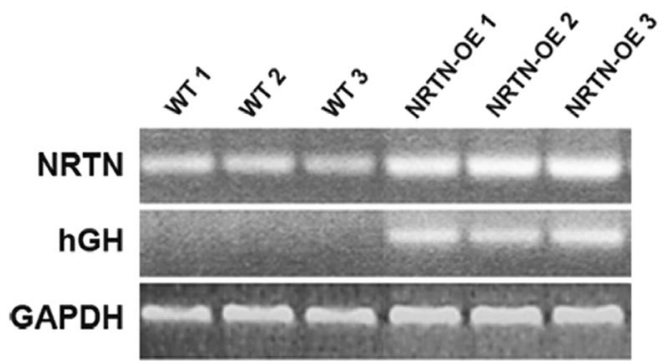

Figure 1. Overexpression of NRTN in the skin is driven by the K14 keratin promoter. $\boldsymbol{A}$, Diagram of the transgene construct used for isolation of NRTN-OE mice. The K14 promoter drives expression of the NRTN sequence (black boxes). The 3' noncoding hGH sequence provides splice sites and a poly $A(P A)$ addition signal. The arrow indicates transcription start site. $B, R T-P C R$ analysis of RNA isolated from WT $(n=3)$ and $\operatorname{NRTN}-0 \mathrm{E}(n=3)$ back skin showing relative level of NRTN mRNA in WT and NRTN-OE skin. Note the enhanced level of NRTN mRNA in NRTN-OE skin and the absence of transgene expression (hGH) in WT skin samples.

(Stucky et al., 2002). Furthermore, GFR $\alpha 2$ KO mice exhibit decreased nocifensive behaviors during the second phase of the formalin test, suggesting a deficit in inflammatory pain signaling (Lindfors et al., 2006).

To further our understanding of NRTN in afferent function, we studied anatomical, neurochemical, and behavioral changes in mice that overexpress NRTN in basal keratinocytes of the epidermis (NRTN-overexpresser [OE]; NRTN-OE mice). NRTN overexpression led to hypertrophy of GFR $\alpha 2$-positive sensory neurons, hyperinnervation of footpad skin, and a marked increase in saphenous nerve diameter. The mRNA levels of $\mathrm{P}_{2} \mathrm{X}_{3}$, the cool-sensitive channel transient receptor potential M8 (TRPM8), and the mechanosensitive channel acid-sensing ion channel 2a (ASIC2a) were also increased in DRG and TG of NRTN-OE mice. In conjunction with these changes in mRNA, behavioral tests showed that NRTN-OE mice had increased cool and menthol sensitivity as well as icreased mechanical sensitivity. These findings indicate that NRTN can modulate the functional properties of cutaneous afferents and expression of a number of genes implicated in nociceptive signaling.

\section{Materials and Methods}

Generation of transgenic mice. NRTN-OE mice were generated and screened following procedures described previously (Albers et al., 1994; Albers et al., 1996; Zwick et al., 2002; Elitt et al., 2006). A 645 bp fragment containing the coding region of mouse NRTN, obtained by restriction digest from IMAGE Clone \#5345262 (GenBank accession number BC057993; Invitrogen), was cloned into the pG4K14pro-human growth hormone (hGH) vector and sequenced to verify orientation. A gel and column purified fragment containing $2.3 \mathrm{~kb}$ of human K14 keratin promoter sequence, $645 \mathrm{bp}$ of the mouse NRTN coding sequence, and $1.4 \mathrm{~kb}$ of the human growth hormone gene containing intron/exon and poly (A) signal sequences (Fig. 1A) was injected into fertilized oocytes from C57BL/6 mice using services provided by the Transgenic and Gene Targeting Core Facility at the University of Pittsburgh. Three founder lines were identified by slot-blot assay of tail skin DNA using transgene- and NRTN-specific random primed ${ }^{32} \mathrm{P}$-dCTP-labeled probes. RT-PCR analysis of total RNA isolated from founder offspring back skin was used to assay the relative level of transgene expression. Detailed analyses of anatomy and behavior were focused on the transgenic line that exhibited the highest transgene expression. Primers to detect endogenous and transgenic NRTN (5'-GGATGTGCCAGGAGGGTCTG $-3^{\prime}$ and $5^{\prime}$ CAGGTCGTAGATGCGGATGG-3') as well as transgene-specific prim- ers ( $5^{\prime}$-ACCGTGCTGTTCCGCTACTG- $3^{\prime}$ and $5^{\prime}$-AAGAGGGCAGCC AGTGTTTCTC-3') were used.

Animals. Experiments were performed on 6- to 8-week-old male wildtype (WT) and age-matched NRTN-OE mice. Mice were housed in group cages except where noted, maintained on a 12:12 h light-dark cycle in a temperature-controlled environment, and given food and water ad libitum. All studies were performed in accordance within guidelines of the Institutional Animal Care and Use Committee at the University of Pittsburgh and the National Institutes of Health Guide for the Care and Use of Laboratory Animals. All behavioral studies were conducted in a blinded fashion in the University of Pittsburgh Rodent Behavioral Analysis Core that is located within the rodent housing facility.

Immunohistochemistry. After deep anesthesia with avertin anesthetic, mice (WT, $n=4$; and NRTN-OE, $n=4$ ) were transcardially perfused with chilled 4\% paraformaldehyde. Glabrous hindpaw skin and L2-L4 DRG were dissected, cryoprotected overnight in $25 \%$ sucrose, embedded in OCT, cut at $20 \mu \mathrm{m}$ using a cryostat and collected on SuperFrost microscope slides. Slides were washed in $0.1 \mathrm{~m}$ phosphate buffer $(\mathrm{PB} ; 3 \times$ $5 \mathrm{~min}$ ), blocked in $5 \%$ normal horse serum with $0.2 \%$ Triton X-100 made in $0.1 \mathrm{M} \mathrm{PB}$ for $1 \mathrm{~h}$, and then incubated overnight at $4^{\circ} \mathrm{C}$ in primary antibodies diluted in blocking solution. Slides were washed in $0.1 \mathrm{M} \mathrm{PB}$ and incubated $1 \mathrm{~h}$ in appropriate secondary antibodies diluted in $0.1 \mathrm{M}$ PB. The primary antibodies used were as follows: goat anti-GFR $\alpha 2$ (1: 500, R\&D Systems), rabbit anti-PGP9.5 (1:1000, Ultraclone), rabbit anticalcitonin gene-related peptide (CGRP) (1:1000, Sigma-Aldrich), rat anti-TRPM8 (1:1000, a generous gift from Masatoshi Takeichi, RIKEN Center for Developmental Biology, Chuo-ku Japan) (Suzuki et al., 2007). The GFR $\alpha 2$ antibody has been used by several laboratories, including our own, to label specifically GFR $\alpha 2$-positive neurons (Malin et al., 2006; Forrest and Keast, 2008). This antibody stains a single band in Western blot analysis and stains no cells in GFR $\alpha 2$ knock-out mice (Voikar et al., 2004; Wanigasekara and Keast, 2006). We have previously published preabsorption studies with the CGRP antiserum and found no staining of sensory ganglia when antibody is preincubated with targeted peptide (Fasanella et al., 2008). The PGP 9.5 specificity was described by Doran et al. (1983). This antibody detects a single band in Western blot analysis for the human version of this neuron-specific ubiquinase and is a standard reagent for labeling peripheral fibers. The specificity of TRPM8 antibody has been tested as previously described (Suzuki et al., 2007). Briefly, incubation of GST-TRPM8 antigen with TRPM8 antiserum blocked the immunostaining of TRPM8 in mouse DRG neurons. In addition, Western blots show that anti-TRPM8 recognizes a major band at $127 \mathrm{kDa}$ in lysates of DRG but not cerebral cortex, which does not express TRPM8.

Secondary antibodies/stains used were as follows: $\mathrm{IB}_{4}$-Cy3 (1:200, Invitrogen), Cy2-conjugated donkey anti-goat (1:1000, Jackson ImmunoResearch Laboratories), and Cy-2 donkey anti-rabbit (1:1000, Jackson ImmunoResearch Laboratories). Slides were coverslipped and photographed using a confocal microscope (Leica Microsystems).

Quantification of PGP and CGRP-positive fibers in skin. NIH ImageJ software was used to quantify the density of PGP9.5- and CGRP-positive fibers in glabrous skin. A "convert to mask" operation was performed to convert fluorescently labeled tissue to black and white such that immunopositive fibers were black against a white background. The epidermis was then outlined, and the percentage of areas containing immunopositive fibers was determined. Adjacent sections of glabrous skin from WT $(n=3)$ and NRTN-OE $(n=3)$ mice were analyzed. One section was stained with PGP9.5, and the adjacent section was stained for CGRP. Three evenly spaced sections were analyzed per animal. Statistical analysis of the data was performed by $t$ test. Using the same images, we also estimated the number of immunopositive nerve fibers in the epidermis as described previously (Lindfors et al., 2006). Briefly, the dermalepidermal junction was traced, its length measured using NIH ImageJ software, and the number of PGP 9.5- or CGRP-positive nerve fibers within each imaged area counted. Data are presented as the number of immunopositive fibers per $100 \mu \mathrm{m}$.

Cell area measurement. A total of $200 \mathrm{GFR} \alpha 2$-positive neurons in the DRG and TG were randomly selected from each animal ( $n=3$ for each genotype) and the cell areas measured using NIH ImageJ software. Statistical significance between groups was determined using a $\chi^{2}$ test. 
Western blotting. Pooled L2-L4 DRG from WT $(n=4)$ and NRTN-OE $(n=4)$ mice were homogenized in SDS lysis buffer and protein concentration determined using the Pierce $660 \mathrm{~nm}$ Protein Assay (Thermo Scientific). A total of $30 \mu \mathrm{g}$ of protein was boiled in $5 \times$ SDS loading buffer for $10 \mathrm{~min}$, separated on an 8\% SDS-PAGE gel, transferred to PVDF membranes, blocked, and incubated with primary antibodies at $4^{\circ} \mathrm{C}$ overnight (rat anti-TRPM8, 1:1000 and rabbit-anti-GAPDH, 1:5000, Santa Cruz Biotechnology). Horseradish peroxidase-coupled secondary antibodies were used for amplification and antibody binding visualized using chemiluminescent detection (Thermo Scientific).

Neuron cell counts. L4 DRG neuron number was estimated as previously described (Harrison et al., 2004; Elitt et al., 2006). Briefly, DRG were collected, postfixed in $4 \%$ paraformaldehyde for $30 \mathrm{~min}$, and cryoprotected overnight in $25 \%$ sucrose. Serial sections $(10 \mu \mathrm{m})$ stained with hematoxylin and eosin were examined at a total magnification of $400 \times$, and a drawing tube was used to record neurons containing one or more nucleoli. Six evenly spaced sections were analyzed per ganglion, and the number of neurons counted was multiplied by the interval between sections. These raw counts were adjusted using a correction factor (percentage of neurons with only one nucleolus) to account for the possibility that individual neurons had multiple nucleoli and could be theoretically counted more than once. This correction factor was multiplied by the raw count to provide an adjusted estimate of cell number. Statistical significance between groups was determined using a $t$ test. The percentage of GFR $\alpha 2$-positive cells was determined using the procedure described by Elitt et al., 2006. The percentage of GFR $\alpha 2 / \mathrm{NeuN}$-positive cells relative to all NeuN-positive cells (used to distinguish neurons from non-neuronal cells) was determined in the L4 and trigeminal ganglia. At least three $40 \times$ fields from a minimum of four nonadjacent sections were counted. Only neurons with visible nuclei were counted to avoid counting errors that could result from neurturin-overexpresser (NRTN-OE) neuron hypertrophy. A minimum of 1000 neurons per animal was counted in at least four WT and four NRTN-OE mice. The same procedure was used to determine the percentage of $\mathrm{IB}_{4}$-positive cells in the $\mathrm{L} 4$ ganglion of WT and NRTN-OE mice.

Electron microscopic analysis of nerve fibers. Saphenous nerves from WT and NRTN-OE mice ( $n=4$ per group) were exposed at mid-thigh level and fixed in situ with $4 \%$ paraformaldehyde and $2 \%$ glutaraldehyde in $0.1 \mathrm{~m}$ PB for $10 \mathrm{~min}$. A $3 \mathrm{~mm}$ segment was removed, postfixed in $4 \%$ paraformaldehyde for $2 \mathrm{~h}$, and washed $3 \times 5 \mathrm{~min}$ in $0.1 \mathrm{M} \mathrm{PB}$. Nerve segments were dehydrated in graded alcohols, infiltrated with propylene oxide, embedded in epoxy resin, and polymerized at $60^{\circ} \mathrm{C}$ for $24 \mathrm{~h}$. Ultrathin sections $(0.7-0.8 \mu \mathrm{m})$ were cut on an ultramicrotome, stained with lead citrate and uranyl acetate, and photographed on an electron microscope. The number of myelinated and unmyelinated axons in nerve cross-sections was counted and axon diameters measured using NIH ImageJ software.

RNA isolation and real-time RT-PCR. RNA was isolated from hindpaw skin, pooled L2-L4 DRG, and pooled TG using RNeasy Mini kits (QIAGEN). RNA ( $1 \mu \mathrm{g})$ was DNase-treated (Invitrogen), reverse-transcribed using Superscript II reverse transcriptase (Invitrogen), and analyzed using SYBR Green PCR as described previously (Malin et al., 2006). Primers were designed using Oligo software (Molecular Biology Insights) and are listed in Table 1. Statistical significance was determined using a $t$ test and Holm's correction (Holm, 1979) for multiple comparisons.

\section{Single-cell PCR analysis}

Single-cell RT-PCR was conducted as previously described (Malin et al., 2011; Schwartz et al., 2011; Wang et al., 2011). Cutaneous afferents were retrogradely labeled by subcutaneous injection of $10 \mu \mathrm{l}$ of $\mathrm{IB}_{4}-488$ (2 $\mu \mathrm{g} / \mu \mathrm{l})$ on the dorsal-medial side of the hindpaw. At $3 \mathrm{~d}$ after injection, DRG cultures were prepared and individual $\mathrm{IB}_{4}$-backlabeled neurons were collected with large-bore $(\sim 50 \mu \mathrm{m})$ glass pipettes and expelled into microcentrifuge tubes containing reverse-transcriptase (RT) mix (Invitrogen). For each experiment, two negative controls were included, either omitting RT or using a cell-free RT mix as template. The first-strand cDNA from back-labeled neurons was used as template in a PCR con-
Table 1. Sequences of primers used for real-time RT-PCR assays

\begin{tabular}{|c|c|c|}
\hline Gene & Forward Primer $\left(5^{\prime}-3^{\prime}\right)$ & Reverse Primer $\left(5^{\prime}-3^{\prime}\right)$ \\
\hline ARTN & GGCCAACCCTAGCTGTTCT & TGGGTCCAGGGAAGCTT \\
\hline $\mathrm{ASIC} 2 \mathrm{a}$ & ATGGACCTCAAGGAGAGCCCCAG & AAGTCTTGATGCCCACACTCCTGC \\
\hline ASIC2b & CGCACAACTTCTCCTCAGTGTTTAC & TTGGATGAAAGGTGGCTCAGAC \\
\hline GAPDH & ATGTGTCCGTCGTGGATCTGA & ATGCCTGCTTCACCACCTTCTT \\
\hline GDNF & AGCTGCCAGCCCAGAGAATT & GCACCCCCGATTTTTGC \\
\hline GFR $\alpha 1$ & GTGTGCAGATGCTGTGGACTAG & TTCAGTGCTTCACACGCACTTG \\
\hline GFR $\alpha 2$ & TGACGGAGGGTGAGGAGTTCT & GAGAGGCGGGAGGTCACAG \\
\hline GFR $\alpha 3$ & CTTGGTGACTACGAGTTGGATGTC & AGATTCATTTTCCAGGGTTTGC \\
\hline Nav 1.8 & GCCACCCAGTTCATTGCCTTTTC & TCCCCAGATTCTCCCAAGACATTC \\
\hline NGF & ACACTCTGATCACTGCGTTTTTG & CCTTCTGGGACATTGCTATCTGT \\
\hline NRTN & TGAGGACGAGGTGTCCTTCCT & AGCTCTTGCAGCGTGTGGTA \\
\hline $\mathrm{P}_{2} \mathrm{X}_{3}$ & TGGAGAATGGCAGCGAGTA & ACCAGCACATCAAAGCGGA \\
\hline p75 & GGGTGATGGCAACCTCTACAGT & GTGTCACCATTGAGCAGCTTCT \\
\hline Piezo 2 & GGCACTAGCATGTGCGTTC & TGTCCTTGCATCGTTGCTTTG \\
\hline Ret & TGAGTGCACCAAGCTTCAGTAC & GCGAAGCCTGGGTCTGTCT \\
\hline Runx1 & TTTCAAGGTACTCCTGCCTGA & CAGTGAGAAGGACCAGAGACT \\
\hline TrkA & AGAGTGGCCTCCGCTTTGT & CGCATTGGAGGACAGATTCA \\
\hline TRPA1 & GCAGGTGGAACTTCATACCAACT & СACTTTGCGTAAGTACCAGAGTGG \\
\hline TRPM8 & CGTGGGAGGGTGTCATGAAG & GTTGTCGTTGGCTTTCGTGTT \\
\hline TRPV1 & TTCCTGCAGAAGAGCAAGAAGC & СCCATTGTGCAGATTGAGCAT \\
\hline
\end{tabular}

taining $1 \times$ GoTaq reaction buffer (Promega), $20 \mathrm{~nm}$ external primers, $0.2 \mu \mathrm{M}$ deoxynucleoside triphosphates, and $0.2 \mu \mathrm{l}$ of GoTaq DNA polymerase (Promega). Each initial PCR product served as template in a subsequent PCR using a nested primer pair $($ TRPAl external primer $=$ CTTCCTGGATTACAACAATGCTCTG, ATGTCCCCAACCGCCAA GC; internal Primer $=$ CAGTGGCAATGTGGAGCAATAG, AAGGAA AGCAATGGGGTGC). Products were electrophoresed on 2\% agaroseethidium bromide gels and photographed. Only samples that amplified the housekeeping gene GAPDH were analyzed.

Calcium imaging. Nonpeptidergic cutaneous afferents (the majority of which express GFR $\alpha 2$ ) were retrogradely labeled by subcutaneous injection of $10 \mu \mathrm{l}$ of $\mathrm{IB}_{4}-488(2 \mu \mathrm{g} / \mu \mathrm{l})$ on the dorsal-medial side of both hindpaws. This site allows preferential labeling of saphenous nerve afferents located in the L2-L3 DRG. At $3 \mathrm{~d}$ after injection, DRG cultures were prepared and analyzed as described previously (Malin et al., 2007). $\mathrm{Ca}^{2+}$ imaging was performed $15-18 \mathrm{~h}$ after plating on neurons labeled for 30 $\mathrm{min}$ at $37^{\circ} \mathrm{C}$ with the $\mathrm{Ca}^{2+}$ indicator dye Fura- $2 \mathrm{AM}(2 \mathrm{mg} / \mathrm{ml}$; Invitrogen). Coverslips were placed on an Olympus microscope stage mount with HBSS buffer flowing at $5 \mathrm{ml} / \mathrm{min}$ and maintained at $30^{\circ} \mathrm{C}$ using a heated stage and in-line heating system (Warner Instruments). Cells with $\mathrm{IB}_{4}-488$ labeling were identified as regions of interest. Emission data at $510 \mathrm{~nm}$ were collected at $1 \mathrm{~Hz}$ with excitation at 340 and $380 \mathrm{~nm}$ and the change in the 340/380 ratio analyzed using SimplePCI software (Compix Imaging Systems). $\mathrm{Ca}^{2+}$ transients were examined in response to brief application of menthol $(250 \mu \mathrm{M})$, capsaicin $(1 \mu \mathrm{M})$, and mustard oil (100 $\mu \mathrm{M})$. Drugs were obtained from Sigma-Aldrich.

\section{Behavioral analysis}

Hargreaves test. WT $(n=10)$ and NRTN-OE $(n=10)$ mice were placed in individual Plexiglas chambers set on a glass plate maintained at $30^{\circ} \mathrm{C}$ (IITC Life Science). Animals were acclimated to the apparatus for $1 \mathrm{~h}$ daily for $3 \mathrm{~d}$ before the day of testing when response latencies (flinching or paw lifting) to noxious thermal stimulation were measured by applying a radiant heat stimulus applied to the glabrous skin of each hindpaw. Three measures from left and right paws (six total) were averaged to obtain a single score for each animal. The experimenter was blinded to mouse genotype. Statistical significance was determined by one-way ANOVA.

Mechanical sensitivity (von Frey filament test). Hindpaw withdrawal frequencies in response to von Frey filament stimulation were performed as described previously (Schwartz et al., 2008). Mice [WT $(n=8)$ and NRTN-OE $(n=8)$ ] were acclimated daily for $30 \mathrm{~min}$ for $3 \mathrm{~d}$ before the day of testing. Mechanical stimuli were applied from below to the plantar 
surface of the right hindpaw $(\sim 2-3 \mathrm{~s})$ and responses to the applied monofilament ( $\mathrm{vF} \# 3.61$, equivalent to $0.4 \mathrm{~g}$ of force) determined. Stimuli were applied 10 times and the number of positive responses converted into a percentage with 10 positive responses corresponding to $100 \%$. The experimenter was blinded to mouse genotype. Statistical significance was determined using a one-way ANOVA.

Two-temperature choice test. WT $(n=20)$ and NRTN-OE $(n=20)$ mice were placed into a thermal gradient apparatus (IITC Life Science) and allowed to explore two adjacent temperature controlled surfaces for $5 \mathrm{~min}$. One surface was held at a constant temperature of $32^{\circ} \mathrm{C}$, and the other ranged in temperature from $4^{\circ} \mathrm{C}$ to $32^{\circ} \mathrm{C}$ (test surface). The time spent on each surface was recorded, and the percentage of time spent on the test surface was calculated. Statistical significance was determined by $t$ tests at each temperature using Holm's correction (Holm, 1979) for multiple comparisons.

Tests for noxious cold responses. WT $(n=20)$ and NRTN-OE $(n=20)$ mice were placed in a Plexiglas container with an ice block floor. The ice block was placed on top of dry ice, and its temperature was maintained at $-20^{\circ} \mathrm{C}$ (monitored using a infrared thermometer). The latency to the first nocifensive response (foot lifting or jumping) and the number of responses in $60 \mathrm{~s}$ were quantified. Mice were also tested using a tail-flick test. Mice $(n=6)$ were placed in Plexiglas holders and allowed to acclimate for $5 \mathrm{~min}$. Their tails were then dipped into $-15^{\circ} \mathrm{C} 95 \%$ ethanol, and the time to the tail-flick response was recorded (Mogil and Adhikari, 1999; Elitt et al., 2006). For all studies, the experimenter was blinded to mouse genotype. Statistical significance for each measure was determined by a $t$ test.

Tests for oral sensitivity. Mice were tested for oral sensitivity to menthol and mustard oil using a modified paired-preference drinking aversion paradigm as described previously (Elitt et al., 2008). Mice were caged individually and given food and water ad libitum. Each cage was fitted with two drinking bottles. On $\mathrm{d} 1$ and $\mathrm{d} 2$, both bottles contained normal water and mice were allowed to drink ad libitum. The volume consumed from each bottle was measured each day to compare baseline drinking between groups. On d3, oral sensitivity to menthol or mustard oil was determined. In tests of menthol sensitivity, one bottle contained normal water plus vehicle $(0.07 \%$ ethanol $)$ and the other bottle contained normal water plus menthol at a concentration of $0.1,1$, or $5 \mathrm{~mm}$. Six mice per group were tested at each menthol concentration (total of $n=18 \mathrm{WT}$ and $n=18$ NRTN-OE). In tests of mustard oil sensitivity, one bottle contained normal water plus vehicle $(0.5 \%$ ethanol $)$ and the other bottle contained normal water plus mustard oil at a concentration of $100 \mu \mathrm{M}$ ( $n=9$ per group) or $300 \mu \mathrm{M}$ ( $n=6$ per group). Separate cohorts of mice were used to test menthol and mustard oil. The experimenter was blinded to the genotype of each mouse tested.

Statistical analysis. Data are expressed as mean \pm SEM. Statistical significance for all analyses was set at $p<0.05$. Data were analyzed using Prism software (GraphPad Software).

\section{Results}

NRTN is increased in skin of NRTN-OE mice

The human epidermal K14 keratin promoter was used to drive NRTN cDNA overexpression in basal keratinocytes of the epidermis (Fig. 1A). This promoter becomes transcriptionally active in developing whisker pad skin at embryonic d10.5 and has been shown to direct high-level expression of NGF, brain-derived neurotrophic factor, neurotrophin 3 (NT-3), GDNF, and artemin (ARTN) to the epidermis when linked to the respective cDNA (Albers et al., 1994; 1996; Zwick et al., 2002; Albers et al., 2006; Elitt et al., 2006). Real-time PCR analysis of back skin showed an increase in NRTN mRNA in transgenic NRTN-OE mice (Fig. $1 B$ ), as did glabrous hindpaw skin, hairy hindpaw skin, and flank skin (11-, 5-, and 3-fold increase, respectively; Table 2). Concomitant with the increase in NRTN was a decrease in GDNF in all skin types assayed (Table 2). Overexpression of NRTN had no overt effect on epidermal (glabrous skin) thickness (WT, $36.11 \pm$ $1.74 \mu \mathrm{m} ; \mathrm{NRTN}=36.45 \pm 3.28 \mu \mathrm{m})$.
Table 2. Change in mRNA level of growth factors in skin of NRTN-0E mice relative to WT mice

\begin{tabular}{lcll}
\hline & \multicolumn{3}{l}{ Percentage change in NRTN-0E } \\
\cline { 2 - 4 } Gene assayed $^{a}$ & Flank skin (\%) & Glabrous skin of hindpaw (\%) & Hairy skin of hindpaw (\%) \\
\hline NRTN & $313^{*}$ & $1123^{*}$ & $485^{*}$ \\
GDNF & $-73^{*}$ & $-56^{*}$ & $-67^{*}$ \\
ARTN & 14 & 8.0 & 12 \\
\hline
\end{tabular}

${ }^{a}$ NRTN was increased in all skin regions tested. ARTN mRNA did not change, whereas GDNF mRNA was decreased in all skin regions tested.

${ }^{*}$ NRTN-OE value significantly differs from WT ( $p<0.05 ; t$ test with Bonferroni correction).

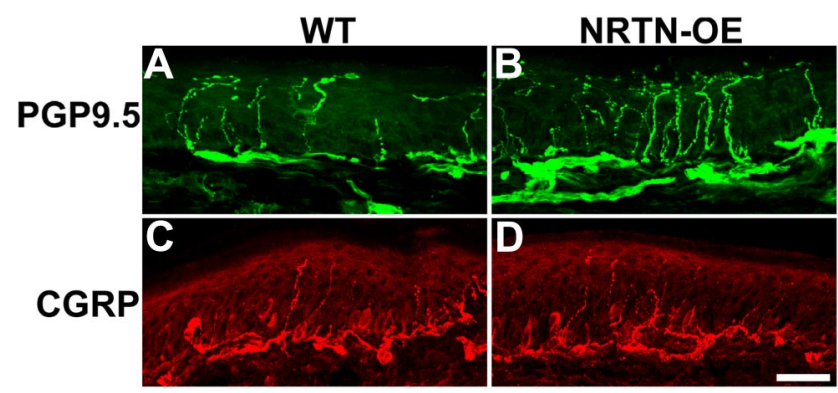

Figure 2. NRTN overexpression increases the density of PGP9.5-positive, but not CGRPpositive, nerve endings in the epidermis of footpad skin. Immunolabeling of glabrous skin from WT $(n=4 ; A, C)$ and NRTN-OE $(n=4 ; \boldsymbol{B}, \boldsymbol{D})$ mice. The number and intensity of PGP9.5-positive fibers are increased in NRTN-OE $(\boldsymbol{B})$ relative to WT $(\boldsymbol{A})$ skin. No change was evident for CGRPpositive fibers between NRTN-OE (D) and WT (C). Scale bar, $25 \mu \mathrm{m}$.

\section{NRTN-OE mice exhibit hypertrophy of peripheral afferent projections}

Most NRTN-responsive/GFR $\alpha 2$-positive neurons are unmyelinated C-fibers (Snider and McMahon, 1998; Stucky and Lewin, 1999) and account for 70\% of cutaneous afferents (Lu et al., 2001). The increase of NRTN mRNA in skin correlated with hyperinnervation by PGP9.5-positive fibers in the epidermis of glabrous hindpaw skin. This is apparent via visual inspection (Fig. 2) and confirmed by measures of PGP9.5-positive fiber density (WT, $4.37 \pm 0.36 \%$; NRTN-OE, $8.05 \pm 0.85 \%$; $n=3, p<0.05$ ) and by counts of fiber number per $100 \mu \mathrm{m}$ (WT, $4.29 \pm 0.38$ fibers $/ 100 \mu \mathrm{m}$; NRTN-OE, $10.99 \pm 1.18 ; p<0.05)$. In contrast, no increase was measured in the density or number of CGRPimmunopositive fibers.

In previous studies, overexpression of NGF, NT-3, GDNF, or ARTN led to an increase in the number of DRG neurons (Albers et al., 1994; 1996; 2006). However, counts of neurons in L4 DRG of WT and NRTN-OE mice showed no difference (WT, $3927 \pm$ 62 ; NRTN-OE, $3930 \pm 54$ ), suggesting that the increased innervation to the skin was the result of hypertrophy of terminal projections of NRTN-responsive afferents.

Low-magnification electron microscopic montages showed that the diameter of the saphenous nerve was larger in NRTN-OE mice (Fig. $3 A, B$ ), although the total number of myelinated and unmyelinated axons was unchanged (Table 3 ). This is consistent with the lack of change in the total DRG neuron number. Interestingly, the mean diameter of both myelinated (WT, $3.64 \pm 0.11 \mu \mathrm{m}$; NRTN-OE, $3.92 \pm 0.23 \mu \mathrm{m}$; $p<0.05)$ and unmyelinated (WT, $0.86 \pm 0.04 \mu \mathrm{m}$; NRTNOE, $1.12 \pm 0.05 \mu \mathrm{m} ; p<0.05)$ axons increased significantly in NRTN-OE mice (Table 3). Moreover, the distribution histogram for unmyelinated axons shows a uniform rightward shift (Fig. 3C). These observations are consistent with the hyper- 
trophy of GFR $\alpha 2$-positive sensory somata and hyperinnervation of the glabrous skin.

Relative to changes in unmyelinated axons, hypertrophy of myelinated axons in NRTN-OE mice was more selective. The greatest effect was seen in the largest fibers (5-6 $\mu \mathrm{m}$ diameter; Fig. 3D), suggesting that NRTN overexpression selectively affects a subset of myelinated cutaneous afferents. This subpopulation may be the large Ret and GFR $\alpha 2$-positive neurons $\left(287 \pm 102 \mu \mathrm{m}^{2}\right)$ that appear early in development (Luo et al., 2009). Early Ret-positive neurons express GFR $\alpha 2$ and neurofilament 200 and are thought to be rapidly adapting mechanoreceptors associated with Meissner corpuscles, Pacinian corpuscles, and longitudinal lanceolate endings (Luo et al., 2009).

\section{NRTN-OE mice exhibit increased GFR $\alpha 2$ and Ret expression}

The canonical receptor complex for NRTN is composed of the Ret receptor tyrosine kinase and GFR $\alpha 2$. All GDNF family ligands bind Ret (although evidence also supports Ret-independent signaling) (Poteryaev et al., 1999; Paratcha et al., 2003; Cao et al., 2008; Schmutzler et al., 2011), whereas the coreceptor GFR $\alpha 2$ confers specificity for NRTN (Heuckeroth et al., 1999; Rossi et al., 1999; Baloh et al.,

$2000 \mathrm{~b})$. Because neurotrophic factors can regulate expression of their cognate receptors (Delcroix et al., 1998; Harrison et al., 2000; Gratto and Verge, 2003), we examined whether increased NRTN affected sensory neuron GFR $\alpha 2$ expression. Immunolabeling of L4 DRG and TG showed a 30\% increase of GFR $\alpha 2$ positive neurons in NRTN-OE DRG (WT, $33.3 \pm 2.6 \%$; NRTN$\mathrm{OE}, 43 \pm 1.3 \% ; p<0.01$ ) and a $25 \%$ increase in the TG (WT, $34.8 \pm 1.8 \%$; NRTN-OE, $46.2 \pm 2.4 \%$; $p<0.01)$. A similar increase $(24 \%)$ in the percentage of cells staining for $\mathrm{IB}_{4}$ was also present; $34.3 \pm 3.2 \%$ of WT L4 neurons were $\mathrm{IB}_{4}$ positive compared with $45.0 \pm 4.9 \%$ of NRTN-OE L4 neurons $(p<0.05)$.

Cell area measures also showed hypertrophy of GFR $\alpha 2$ expressing neurons in both TG (WT, $164.6 \pm 3.0 \mu \mathrm{m}^{2}$; NRTNOE, $335.5 \pm 7.6 \mu \mathrm{m}^{2} ; p<0.001$; Fig. $4 A-F$ ) and L4 DRG (WT, $196.0 \pm 4.5 \mu \mathrm{m}^{2}$; NRTN-OE, $290.4 \pm 8.2 \mu \mathrm{m}^{2} ; p<0.001$; Fig. $4 G-L)$. The size distribution of GFR $\alpha 2$-positive somata in both DRG and TG showed a significant rightward shift (Fig. $4 M, N$ ). In addition, real-time RT-PCR analysis showed GFR $\alpha 2$ mRNA increased $62 \%$ in pooled lumbar DRG and $98 \%$ in TG, whereas Ret mRNA increased 77\% in DRG and $144 \%$ in TG of NRTN-OE mice (Table 4). The mRNA levels for the NGF receptors, tyrosine kinase A (TrkA) and p75, were unchanged (Table 4). There also was no change in GFR $\alpha 1$ mRNA, although GFR $\alpha 3$ mRNA was significantly decreased in NRTN-OE mice $(-32 \%$ in DRG and $-28 \%$ in TG; Table 4). Given that there was no increase in the number of DRG neurons, these data indicate that the increase in expression of GFR $\alpha 2$ and Ret occurs on a per cell basis, and perhaps by de novo synthesis in some cells.
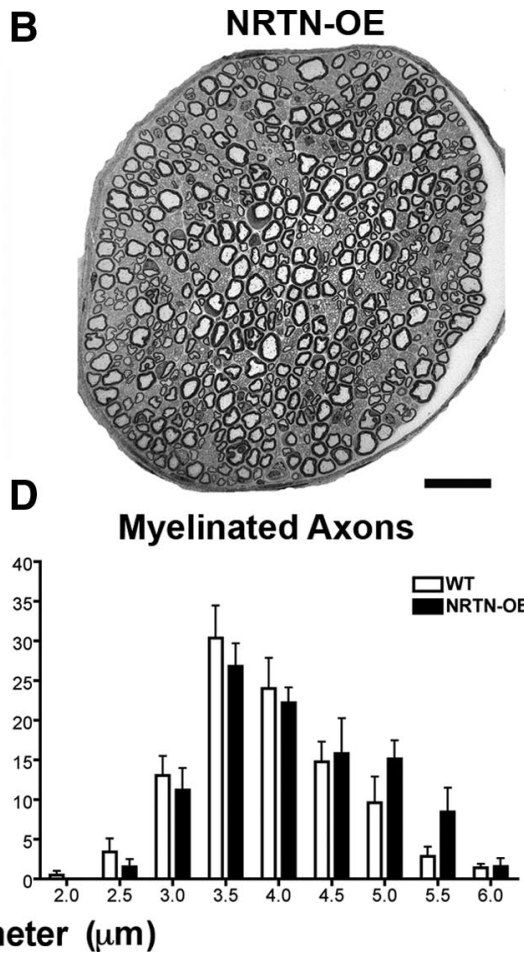

Axon diameter $(\mu \mathrm{m})$

Figure 3. NRTN overexpression increases the diameter of myelinated and unmyelinated axons in the saphenous nerve. Low位 NRTN-OE mice (Table 2). For unmyelinated axons, a significant rightward shift of the entire population occurs (two-way ANOVA $p<0.05)$. For myelinated axons, an enlargement of the largest-diameter axons $(>4.5 \mu \mathrm{m})$ occurs. Scale bar, $20 \mu \mathrm{m}$.

Table 3. Number and diameter of myelinated and unmyelinated fibers in the saphenous nerve of WT and NRTN-OE mice

\begin{tabular}{lrr}
\hline No./diameter/thickness & \\
& & \\
\hline No. of myelinated axons & & \multicolumn{1}{c}{ NRTN-0E } \\
No. of unmyelinated axons & $556.25 \pm 14.64$ & $550.5 \pm 21.17$ \\
Diameter of myelinated axons $(\mu \mathrm{m})$ & $2472.25 \pm 83.78$ & $2430.25 \pm 44.95$ \\
Diameter of unmyelinated axons $(\mu \mathrm{m})$ & $3.64 \pm 0.11$ & $3.92 \pm 0.23^{*}$ \\
Myelin thickness $(\mu \mathrm{m})$ & $0.86 \pm 0.04$ & $1.12 \pm 0.05^{*}$ \\
\hline
\end{tabular}

The number of myelinated and unmyelinated axons in the saphenous nerve was unchanged in NRTN-OE mice. However, the average diameter of both populations was increased. Myelin thickness was unchanged. ${ }^{*}$ NRTN-OE $>$ WT $(p<0.05 ; t$ test $)$.

\section{NRTN-OE mice exhibit increased TRPM8 expression}

Several TRP nonselective cation channel family members are expressed in cutaneous afferents. The relative expression of three genes within this family with putative functions in heat (TRPV1) and cool/ cold (TRPM8 and TRPA1) thermosensation were examined in NRTN-OE mice using real-time RT-PCR. No significant change in TRPV1 mRNA expression occurred in NRTN-OE ganglia (Table 4). However, the mRNA level of TRPM8 was significantly increased in both lumbar DRG and TG ( $44 \%$ and $84 \%$, respectively; $p<0.05$ ) of NRTN-OE mice relative to WT mice. TRPA1 was also increased (74\% in DRG; $42 \%$ in TG; $p<0.05$; Table 4 ).

To determine whether the number of TRPM8-expressing neurons was increased, we performed two experiments using $\mathrm{IB}_{4}{ }^{-}$ labeled cells as our reference population (as most of these neurons are NRTN-responsive). In the first experiment, L4 DRG were colabeled using an antibody to TRPM8 and $\mathrm{IB}_{4}$-conjugated Cy3. No double-labeled cells were seen in WT mice $(n=4)$, 


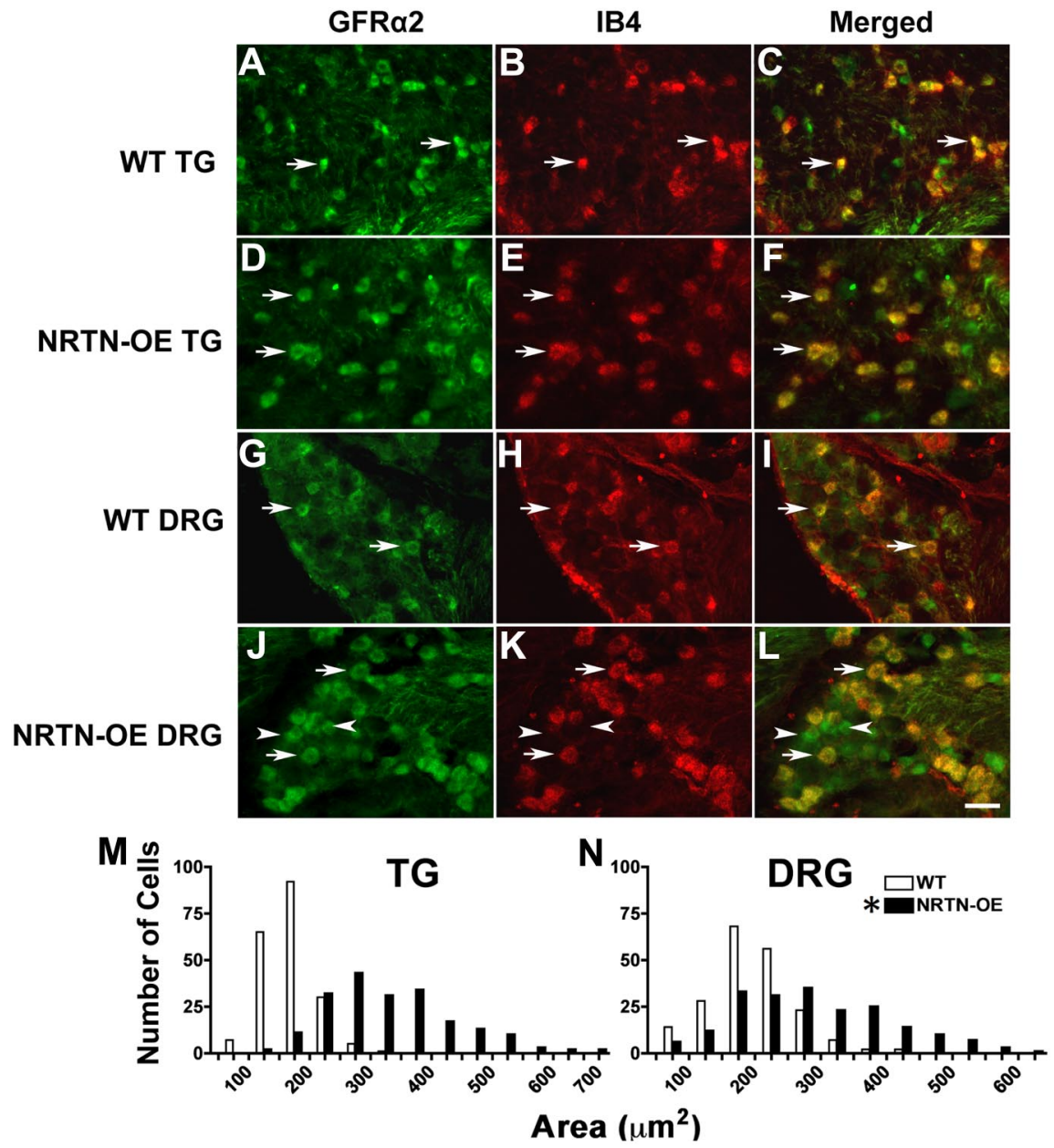

Figure 4. Somas of NRTN-responsive neurons are hypertrophied. GFR $\alpha 2$-positive/IB 4 -binding neurons (arrows) from NRTN-OE mice $(n=4)$ appeared larger relative to WT neurons $(n=4)$ in the TG (compare $\boldsymbol{A}-\boldsymbol{C}$ with $\boldsymbol{D}-\boldsymbol{F}$ ) and DRG (compare $\mathbf{G}-\mathbf{I}$ with $\boldsymbol{J}-\boldsymbol{L}$ ). In WT DRG, GFR $\alpha 2$-positive/IB ${ }_{4}$-negative neurons were rare, whereas in the NRTN-0E mice, numerous GFR $\alpha 2$-positive/IB ${ }_{4}^{-}$ negative neurons could be found ( $\boldsymbol{J}-\boldsymbol{L}$; arrowheads). The size distribution of somal areas of GFR $\alpha 2$-positive neurons for TG and DRG is shown in $\boldsymbol{M}$ and $\boldsymbol{N}$, respectively. A significant rightward shift in TG and DRG populations in NRTN-0E ganglia occurs, indicating hypertrophy of GFR $\alpha 2$-positive//B ${ }_{4}$-binding neurons. *NRTN-OE $>$ WT ( $\chi^{2}$ test, $p<0.05$ ). confirming the results of McKemy and coworkers who used a TRPM8 reporter mouse and found that TRPM8 is only expressed in $\sim 8 \%$ of L4 DRG neurons, all of which are $\mathrm{IB}_{4}$-negative (Takashima et al., 2010). However, in NRTN-OE mice, the overlap between $\mathrm{IB}_{4}$ and TRPM8 was $40.0 \pm 7.4 \%(n=4)$, indicating that in NRTN-OE mice the percentage of TRPM8-positive cells may be increased by as much as $18 \%$; i.e., $\mathrm{IB}_{4}$-positive cells account for $45 \%$ of the somatic profiles in the NRTN-OE L4 DRG (above) and 40\% of these are TRPM8-positive $(45 \% \times$ $0.4=18 \%)$. In the second experiment, $\mathrm{IB}_{4}$ 488 was injected into the glabrous skin of the hindpaw, and the overlap between backlabeled neurons and TRPM8 was determined. In WT mice, very few $\mathrm{IB}_{4}$-binding neurons were TRPM8-immunoreactive $(6.0 \%, n=4$; Fig. 5$)$, whereas in NRTN-OE mice, $70 \%(n=4)$ were TRPM8-positive. The fact that a higher percentage of NRTN$\mathrm{OE}, \mathrm{IB}_{4}$-back-labeled neurons expressed TRPM8 then did the entire $\mathrm{IB}_{4}$ population (Experiment 1) indicates that the effect of NRTN overexpression was specific for cutaneous afferents.

The TRPM8-positive $\mathrm{IB}_{4}$-binding neurons exhibited size heterogeneity. Measurement of somal diameter of neuronal profiles revealed that in WT mice only $15 \%$ of TRPM8-positive cells were $\geq 30$ $\mu \mathrm{m}$, whereas $55 \%$ of NRTN-OE TRPM8positive profiles were $\geq 30 \mu \mathrm{m}$. These larger cells were lightly labeled relative to the population of smaller cells, similar to reports describing TRPV1 labeling (Chen et al., 2006). Immunoblot analysis also showed an increase in TRPM8 protein level in the DRG of NRTN-OE mice compared with WT mice (Fig. 5G). Together, these results suggest that, in NRTN-OE ganglia, either a dramatic hypertrophy of TRPM8-expressing cells occurs or neurons that normally do not express TRPM8 begin to do so. Given the large increase in the number of TRPM8-immunopositive cells, the second possibility seems more likely.

Because we did not have access to a validated antibody for TRPA1, we performed single-cell PCR on lumbar DRG neurons retrogradely labeled from hindpaw skin with $\mathrm{IB}_{4}$ to determine the percentage that express TRPA1 mRNA. There was no difference in this percentage between WT and NRTN-OE mice (WT, $56 \pm$ $2.16 \%$; NRTN-OE, $47 \pm 2.87 \% ; n=4 ; p>0.05)$. However, the percentage of cells expressing TRPA1 mRNA was higher than predicted based on previous calcium imaging functional studies (only 19\% of WGA back-labeled afferents exhibited mustard oilinduced calcium signals) (Malin et al., 2011). We therefore conducted calcium imaging studies on $\mathrm{IB}_{4}$-positive cells retrogradely labeled from hindpaw skin. We found no difference between WT and NRTN-OE in the percentage of cells responding to the TRPA1 agonist, mustard oil (WT, $29.4 \pm 4.1 \%$; NRTN-OE, $21.0 \pm 3.9 \% ; n=4 ; p>0.05$ ), although the percentage of responders was notably less than the percentage expressing TRPA1 
mRNA. This finding suggests that a population of cutaneous afferents contain TRPA1 mRNA but do not produce protein and functional TRPA1 channels.

\section{NRTN-OE mice do not exhibit altered} behavioral sensitivity to noxious heat NRTN-responsive neurons make up the majority of fibers innervating the epidermis and functionally these afferents are primarily polymodal nociceptors responsive to mechanical and heat stimuli. Electrophysiological analysis of dissociated DRG neurons from GFR $\alpha 2 \mathrm{KO}$ mice showed that NRTN/GFR $\alpha 2$ receptor signaling is required for noxious heat responses (Stucky et al., 2002). To test whether changes in sensitivity to noxious heat occur in vivo in mice that overexpress NRTN, glabrous hindpaw withdrawal latencies were measured in response to noxious radiant heat. Withdrawal latencies were not different between WT and NRTN-OE mice (WT, $11.21 \pm 1.59 \mathrm{~s}$; NRTN-OE, $9.81 \pm 1.43 \mathrm{~s}$ ), indicating that overexpression of NRTN does not alter sensitivity to noxious heat. This is consistent with the lack of change in TRPV1 mRNA expression in NRTN-OE ganglia.

\section{NRTN-OE mice exhibit increased behavioral sensitivity to innocuous cold stimuli}

The observed change in NRTN-OE lumbar DRG expression of TRPM8, a channel activated by menthol or temperatures $<25^{\circ} \mathrm{C}$ (McKemy et al., 2002; Peier et al., 2002; Bautista et al., 2007), suggested that sensitivity to cool stimuli may be altered in NRTN-OE mice. A two-temperature choice test was used to determine whether NRTN-OE mice had increased sensitivity to innocuous cold. The reference temperature was set at $32^{\circ} \mathrm{C}$ because preliminary experiments showed that both WT and NRTN-OE mice spent the greatest amount of time at this temperature when allowed to explore a continuous gradient of $16^{\circ} \mathrm{C}$ to $45^{\circ} \mathrm{C}$ (data not shown). When the temperature of both keys was maintained at $32^{\circ} \mathrm{C}$ in the two-choice temperature test, mice spent equal time on each key, indicating no preference for right and left keys. Both WT and NRTN-OE mice showed a preference for the $32^{\circ} \mathrm{C}$ control key when the temperature of the variable key ranged from $4^{\circ} \mathrm{C}$ to $26^{\circ} \mathrm{C}$. However, NRTN-OE mice spent significantly more time than WT mice on the $32^{\circ} \mathrm{C}$ control key relative to the variable key at the test temperatures of $17^{\circ} \mathrm{C}$ and $20^{\circ} \mathrm{C}(p<0.01)$, indicating increased sensitivity to cooling (Fig. $6 A)$. NRTN-OE mice also showed a trend for increased sensitivity to $14^{\circ} \mathrm{C}$, although this did not reach statistical significance $(p=$ 0.082 ).

Because NRTN-OE mice expressed more TRPA1 mRNA per ganglia (Table 4) and because there is still controversy as to whether this TRP channel can mediate sensitivity to noxious cold (Bautista et al., 2006; da Costa et al., 2010; del Camino et al., 2010; Chen et al., 2011), we tested the NRTN-OE mice in two assays using noxious cold stimuli. In the first assay, mice were placed on a wet ice block sitting on dry ice (an infrared thermometer reported a consistent temperature of $-20^{\circ} \mathrm{C}$ ). Latency to the first nocifensive response and the number of responses were deter$\mu \mathrm{m}$.
$\mathrm{IB}_{4}$ TRPM8
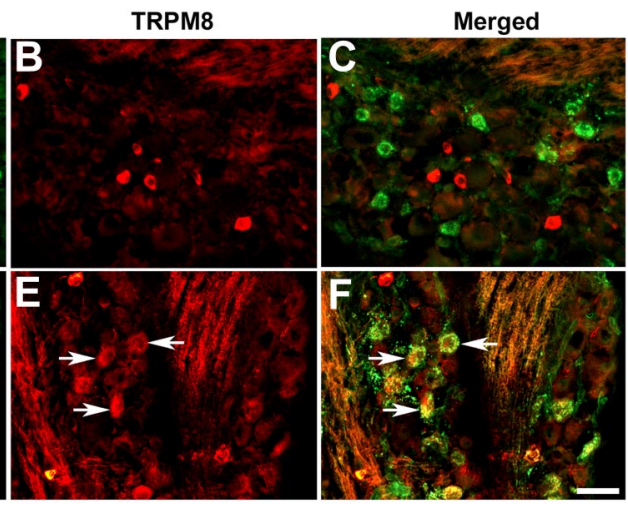

Merged
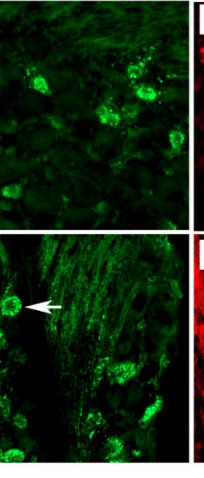
.

Figure 5. NRTN overexpression increases the number and size of TRPM8-positive/IB ${ }_{4}$-binding neurons. In WT DRG ( $\left.\boldsymbol{A}-\boldsymbol{C}\right)$, TRPM8 staining was not detectable in $\mathrm{IB}_{4}$-binding neurons, whereas in NRTN-OE DRG $(\boldsymbol{D}-\boldsymbol{F})$, most $\mathrm{IB}_{4}$-binding neurons express was greater in DRG from NRTN-OE mice. TRPM8 protein was undetectable in WT ganglia under the conditions used. Scale bar, 20

mined. The second test was a tail flick assay using $-15^{\circ} \mathrm{C}$ circulating ethanol bath. Surprisingly, in both assays, the NRTN-OE mice were less sensitive than WT mice (Fig. $6 B, C$ ). In the ice block test, NRTN-OE mice had a longer latency (NRTN-OE, $21.7 \pm 1.7 \mathrm{~s} ; \mathrm{WT}, 13.3 \pm 0.85 \mathrm{~s} ; n=20 ; p<0.05)$ to the first response and subsequently exhibited fewer responses (NRTNOE, $15.6 \pm 1.36$; WT, $21 \pm 1.5, n=20 ; p<0.05)$. A longer latency was also seen in the tail flick test (NRTN-OE, $9.8 \pm 1.3 \mathrm{~s}$; WT, $5.8 \pm 1.1 \mathrm{~s} ; n=6 ; p<0.05)$.

NRTN-OE mice exhibit increased oral sensitivity to menthol Because TRPM8 was increased in the TG of NRTN-OE mice relative to WT (84\%, Table 4), and TRPM8-expressing neurons in the TG have branches in lingual nerve fibers that innervate the tongue (Abe et al., 2005), oral sensitivity to menthol, a TRPM8 ligand, was assessed using a two-bottle drinking aversion test. During the acclimation period, all mice drank the same volume of water from each bottle and did not display a bottle preference (data not shown). On the test day, one bottle was filled with vehicle $(0.07 \%$ ethanol in normal water), and the other was filled with menthol solution at $0.1,1$, or $5 \mathrm{~mm}$ concentration. Neither WT nor NRTN-OE mice exhibited a bottle preference at the lowest menthol concentration. However, at concentrations of 1 and $5 \mathrm{~mm}$ menthol, both WT and NRTN-OE mice drank less menthol-containing water relative to vehicle-containing water, and NRTN-OE mice consumed significantly less compared with WT mice (Fig. 6D). This result suggests that NRTN-OE mice had increased oral sensitivity to menthol.

Having seen no changes in thermal behavior that potentially correlated with the increase in TRPA1 expression, we tested whether there was an impact on oral sensitivity to mustard oil. In previous studies, we found that mice with increased TRPA1 expression in response to transgenic expression of artemin (ARTN-OE mice) in the oral epithelium exhibited decreased consumption of water-containing mustard oil (Elitt et al., 2008). 

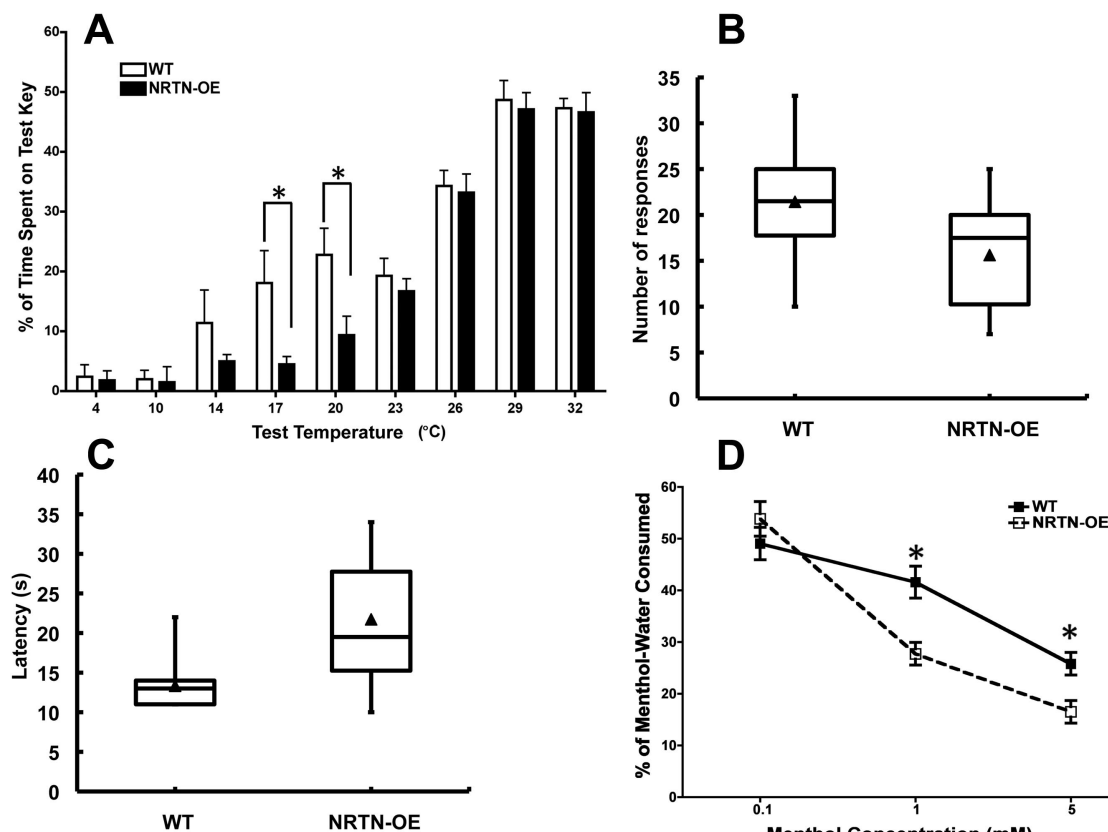

D

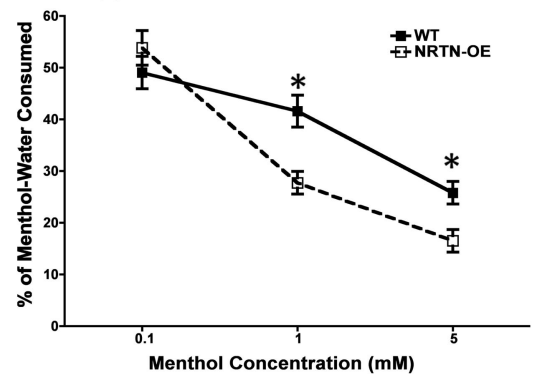

Figure 6. NRTN-OE mice have increased sensitivity to innocuous cold temperature and oral menthol. $\boldsymbol{A}, \mathrm{A}$ two-temperature choice test was performed in which mice explored two adjacent temperature-controlled keys for $5 \mathrm{~min}$. The control key was held at a constant $32^{\circ} \mathrm{C}$, whereas the test key ranged from $4^{\circ} \mathrm{C}$ to $32^{\circ} \mathrm{C}$. Data are plotted as percentage of time spent on the test key ( $y$-axis) as a function of test temperature ( $x$-axis). No preference was displayed by NRTN-OE $(n=20)$ or WT $(n=20)$ mice at test temperatures of $29^{\circ} \mathrm{C}$ and $32^{\circ} \mathrm{C}$ (i.e., they spent $\sim 50 \%$ of the time on both keys). When the temperature of the test key was $<29^{\circ} \mathrm{C}$, both NRTN-OE and WT mice spent less time on the test key relative to the control key, indicating a preference for $32^{\circ} \mathrm{C}$ NRTN-OE mice spent significantly less time than WT mice at the $17^{\circ} \mathrm{C}$ and $20^{\circ} \mathrm{C}$ test temperatures. ${ }^{*}$ NRTN-OE $<$ WT ( $t$ tests; at each temperature). $\boldsymbol{B}$, NRTN-OE mice have decreased sensitivity to noxious cold on wet ice block. Plot shows that NRTN-OE mice placed on $\mathrm{a}-20^{\circ} \mathrm{C}$ surface have a longer latency to their first nocifensive response than WT mice ( $p<0.05 ; t$ test). C, NRTN-0E mice also had fewer responses during the ice block trial period ( $p<0.05 ; t$ test). $D$, WT $(n=6)$ and NRTN-0E $(n=6)$ mice were tested for oral sensitivity to menthol using a two-bottle drinking aversion assay. One bottle contained water with vehicle $(0.07 \%$ ethanol), and the other bottle contained water with menthol $(0.1,1$, and $5 \mathrm{~mm})$. At the lowest concentration $(0.1 \mathrm{~mm})$, both WT and NRTN-0E mice drank equal amounts of vehicle and menthol solutions, exhibiting no preference. At menthol concentrations of 1 and $5 \mathrm{~mm}$, both WT and NRTN-OE mice drank less menthol solution compared with baseline, and NRTN-OE mice drank significantly less menthol-water than WT mice. *NRTN-OE $<$ WT ( $p<0.05$; two-way ANOVA and Bonferroni post hoc test).

Using a similar test with $100 \mu \mathrm{M}$ mustard oil (the concentration that revealed hypersensitivity in the ARTN-OE mice), NRTN-OE and WT mice drank the same amount of water and mustard oil solution (water: WT, $3.96 \pm 0.66 \mathrm{ml}$; NRTN-OE, $4.71 \pm 0.55 \mathrm{ml}$; mustard oil: WT, $1.28 \pm 0.12 \mathrm{ml}$; NRTN-OE, $1.23 \pm 0.26 \mathrm{ml} ; n=$ $9 ; p>0.05)$. We also tested a higher mustard oil concentration (300 $\mu \mathrm{M})$; although both groups of mice drank less of this mustard oil solution compared with the $100 \mu \mathrm{M}$ concentration, no difference was measured between WT and NRTN-OE mice (water: WT, $3.35 \pm 0.17 \mathrm{ml}$; NRTN-OE, $4.96 \pm 0.49 \mathrm{ml}$; mustard oil: WT, $0.49 \pm$ $0.07 \mathrm{ml}$; NRTN-OE, $0.71 \pm 0.09 \mathrm{ml} ; n=6 ; p>0.05)$.

\section{NRTN-OE cutaneous sensory neurons exhibit increased response to menthol}

Overexpression of NRTN increased TRPM8 mRNA and protein in sensory neurons and increased behavioral responses to cold and menthol stimuli, suggesting that NRTN enhances TRPM8mediated responses in sensory neurons. To examine TRPM8 activation, we used ratiometric $\mathrm{Ca}^{2+}$ imaging to assess how WT and NRTN-OE cutaneous sensory neurons responded to the TRPM8 agonist menthol. Nonpeptidergic cutaneous afferents (primarily those expressing GFR $\alpha 2$ ) (Malin et al., 2011) were retrogradely labeled with $\mathrm{IB}_{4}-488$. Dissociated L2-L4 DRG neurons were briefly exposed to $250 \mu \mathrm{M}$ menthol followed by $10 \mathrm{~min}$ of flowing buffer and application of $1 \mu \mathrm{M}$ capsaicin, during which
$\mathrm{Ca}^{2+}$ transients were imaged (Fig. 7). In WT mice, $14.02 \pm 1.38 \%$ of $\mathrm{IB}_{4}-488$ labeled neurons responded to menthol, whereas the percentage was significantly increased to $48.81 \pm 1.68 \%$ in NRTN-OE mice $(n=3 ; p<0.05)$. Some of this increase might result from the increase in the percentage of $\mathrm{IB}_{4}$-expressing neurons ( $24 \%$ greater in NRTN-OE mice), but this can account for only a fraction of the difference in increased responsiveness to menthol. The magnitude of the mentholevoked calcium transient was unchanged between WT and NRTN-OE neurons. There was no change in the number of $\mathrm{IB}_{4}-488$ labeled cells that responded to capsaicin (NRTN-OE, $32.3 \pm 0.47$; WT, $30.3 \pm 0.31 ; n=3, p>0.05)$ or mustard oil (NRTN-OE, $26.5 \pm 7.9$; WT, $20.9 \pm$ $8.2 ; n=4, p<0.05)$, and the size of these responses was not different. These data suggest that skin-derived NRTN modulates menthol sensitivity in a TRPM8specific manner.

\section{NRTN-OE mice exhibit increased mechanical sensitivity}

Behavioral tests for mechanical sensitivity of WT and NRTN-OE mice showed that overexpression of NRTN significantly increased mechanical sensitivity, as defined by the percentage of responses to applied von Frey filaments (NRTN-OE, $42.5 \pm$ $3.85 \%$; WT, $20.0 \pm 2.50 \% ; n=20 ; p<$ $0.05)$. A similar increase in mechanical sensitivity was observed previously in mice overexpressing GDNF (Albers et al., 2006). This raises the possibility that NRTN and GDNF level modulates mechanical sensitivity in cutaneous afferents, possibly via changes in the expression of mechanical transducers. One candidate is ASIC2a, a splice variant of the proton-gated sodium channel ASIC2 that is required for mechanical sensitivity in myelinated low-threshold mechanoreceptors (Price et al., 2000). In NRTN-OE mice, ASIC2a expression was significantly increased in both DRG and TG (95\% and $125 \%$, respectively; $p<0.05$ ) relative to WT mice. It is possible that increased expression of ASIC2a in cutaneous unmyelinated afferents increases their sensitivity to mechanical stimuli. However, in the absence of specific ASIC2 agonists, this suggestion is speculative. Finally, another DRGexpressed, mechanically sensitive gene, piezo 2 (Coste et al., 2010), was examined. No significant increase in NRTN-OE mice was found (Table 4).

\section{Discussion}

The findings of this study show that target-derived overexpression of NRTN in skin increases the number of cutaneous neurons that express phenotypic markers associated with NRTNresponsive afferents (i.e., GFR $\alpha 2$ and Ret mRNA and $\mathrm{IB}_{4}$ binding). NRTN overexpression also led to an increase in the level of TRPM8 expression and enhanced behavioral sensitivity to cool and menthol, both likely the result of the increase in TRPM8. The phenotypic changes were greatest in the TG, similar to what has 
been seen in other transgenic lines overexpressing growth factors (Albers et al., 1994, Albers et al., 1996, Albers et al., 2006) and is probably related to the dense projection of TG neurons to the whisker pad and oral epithelium.

The increased mechanical sensitivity of NRTN-OE mice, similar to the phenotype of GDNF-OE mice, is likely the result of changes in the response properties of unmyelinated cutaneous afferents. We cannot rule out the possibility that changes in the properties of myelinated afferents that express GFR $\alpha 2$ during development contributed to the mechanosensory phenotype; however, the majority of these afferents innervate hairy skin, whereas sensory thresholds were tested here in glabrous skin. (Luo et al., 2009; Li et al., 2011). It should also be noted that $\mathrm{IB}_{4}$-positive polymodal nociceptors have a wide range of mechanical thresholds, including some that are surprisingly low (e.g., some $\mathrm{IB}_{4}$-positive CPM respond to $1 \mathrm{mN}$ von Frey hairs (Woodbury et al., 2004; their Fig. 2).

Unlike overexpression of the growth factors NGF, NT-3, or ARTN, overexpression of NRTN did not increase total DRG neuron number (Albers et al., 1994; Albers et al., 1996; Albers et al., 2006). However, the percentage of GFR $\alpha 2$-expressing and $\mathrm{IB}_{4}$-positive neurons was significantly increased. Although it is possible that NRTN overexpression increased survival of GFR $\alpha 2$ positive neurons and a concomitant and equal loss of another neuron population, this seems unlikely because the majority of GFR $\alpha 2$ expression appears late in development (Luo et al., 2007), after the greatest period of developmental programmed cell death (Davies and Lumsden, 1984; Mendell et al., 1999; Huang and Reichardt, 2001). Interestingly, RNA expression analysis showed a decrease in GFR $\alpha 3$ in DRG and TG that could have resulted if some GFR $\alpha 3$-expressing neurons expressed GFR $\alpha 2$ in response to increased NRTN levels. During mouse development (extending into early postnatal times), some DRG neurons do express both GFR $\alpha 2$ and GFR $\alpha 3$ (Baudet et al., 2000), allowing such a switch between GFR $\alpha 2$ and GFR $\alpha 3$ phenotype to exist. This mechanism is further supported by studies of regenerating peripheral nerves that show a near-complete loss of GFR $\alpha 2$ expression coupled with a doubling of GFR $\alpha 1$ - and GFR $\alpha 3$ immunopositive neurons (Baudet et al., 2000).Together, these results suggest that the increase in the percentage of neurons expressing GFR $\alpha 2$ in the NRTN-OE mice is the result of upregulation of GFR $\alpha 2$ expression in cells that do not normally express detectable levels, and not as a result of increased cell survival.

In addition to an increased number of GFR $\alpha 2$-positive neurons in NRTN-OE mice, the average somal diameter of GFR $\alpha 2$ positive neurons increased, as did axonal diameter in the saphenous nerve, skin innervation density, and the number of PGP 9.5-positive fibers in the skin. These results complement previous findings in GFR $\alpha 2 \mathrm{KO}$ and NRTN KO mice: both knock-out lines exhibited a reduction in the size of GFR $\alpha 2$ positive/ $\mathrm{IB}_{4}$-binding sensory somata, saphenous axonal diameter, and density of nonpeptidergic free nerve endings in footpad skin (Heuckeroth et al., 1999; Stucky et al., 2002; Lindfors et al., 2006). In combination, these results suggest that NRTN is not required for neuron survival but instead regulates peripheral innervation density as well as the axonal and somatic diameter of GFR $\alpha 2$-positive neurons.

One of the most striking findings of our characterization of the NRTN-OE mice was the robust increase observed in TRPM8
mRNA, protein, and functional properties as measured by sensitivity to cool temperatures and menthol. In a TRPM8 reporter mouse line, the percentage of neurons that express TRPM8 in P14 lumbar ganglia is estimated to be $\sim 8 \%$ (Takashima et al., 2010). The increase in the percentage of retrogradely $\mathrm{IB}_{4}$-labeled cells expressing TRPM8 was large (NRTN-OE $=70 \%$ vs WT $=6 \%$ ), and this was coupled with an equally impressive increase in the percentage of TRPM8-positive cells with diameters $>30 \mu \mathrm{m}$ $(\mathrm{NRTN}-\mathrm{OE}=55 \% \mathrm{vs} \mathrm{WT}=15 \%)$. These results suggest that cells that do not normally express detectable levels of TRPM8 do so in the NRTN-OE mice. How NRTN/Ret-GFR $\alpha 2$ signaling upregulates TRPM8 expression in GFR $\alpha 2$-positive neurons is not clear. A potential regulatory molecule is the transcription factor Runx1. GFR $\alpha 2$ and TRPM8 gene expression requires Runx1, as no TRPM8 expression is detected in Runx1 KO mice (Chen et al., 2006). Runx1 also regulates the expression of $\mathrm{P}_{2} \mathrm{X}_{3}$, the expression of which is increased in NRTN-OE DRG and TG, suggesting that Runx1 function is stimulated in NRTN-OE neurons. Real-time PCR analysis of NRTN-OE DRG shows that Runx1 is increased 38\% in DRG and 76\% in TG (Table 4). Embryonic NRTN overexpression (starting at E10.5) could therefore induce upregulation of Runx1, resulting in increased expression of TRPM8 and P2 $\mathrm{X}_{3}$. TRPV1 expression is also regulated by Runx1 but is not increased in neurons of NRTN-OE mice. This may reflect cell type-specific regulation of Runxl function (Chen et al., 2006).

The drinking aversion test revealed NRTN-OE mice to be hypersensitive to the TRPM8 ligand menthol, which likely reflects the increase in TRPM8 in TG neurons. Several groups have characterized TRPM8 expression in TG and tongue (Abe et al., 2005; Kobayashi et al., 2005), as well as GFR $\alpha 2$ expression in lingual ganglia (Nosrat, 1998). NRTN overexpression in the tongue appears to increase TRPM8 expression in TG neurons, thereby increasing oral sensitivity to menthol. Coupled with the aversion to oral menthol was an aversion to cool temperatures in NRTN-OE mice. TRPM8 is activated by cooling temperature between $18^{\circ} \mathrm{C}$ and $25^{\circ} \mathrm{C}$ and required for avoidance of innocuous cold (Bautista et al., 2007; Colburn et al., 2007; Dhaka et al., 2007). These observations confirm the importance of the fiber type that is stimulated with respect to the behavioral outcome. That is, even if the stimulus is "nonthreatening," if the afferent is connected to a nociceptive pathway, as is the case for these polymodal nociceptors expressing TRPM8, the behavioral response will be similar to that seen after exposure to a legitimate noxious input.

In previous behavioral studies of GFR $\alpha 2 \mathrm{KO}$ mice, no change in response to noxious heat was observed (Lindfors et al., 2006). This observation is consistent with the lack of heat hypersensitivity we observed in NRTN-OE mice (i.e., the level of NRTN/ GFR $\alpha 2$ signaling does not appear to affect the behavioral response to noxious heat). However, these behavioral results 
from both the GFR $\alpha 2 \mathrm{KO}$ and NRTN-OE mice are inconsistent with an in vitro study that found a decrease in heat sensitivity of $\mathrm{IB}_{4}$-positive neurons isolated from GFR $\alpha 2 \mathrm{KO}$ mice (Stucky et al., 2002). Given the anatomical atrophy that occurs in GFR $\alpha 2$ null neurons (Lindfors et al., 2006), it is reasonable to assume that their ability to respond to appropriate stimuli would be reduced. However, it is surprising that the GFR $\alpha 2 \mathrm{KO}$ mice exhibited normal behavioral heat responses because epidermal innervation by polymodal nociceptors is greatly reduced (Lindfors et al., 2006). Likewise, it was unexpected that skin hyperinnervation in NRTN-OE mice was not accompanied by increased sensitivity to noxious heat. These results highlight the resilience of the sensory nervous system in accommodating alterations in anatomical substrates and the expression of critical regulatory proteins.

Phylogenetic analysis indicates that orthologs of all four GFR $\alpha$ receptors are present in all vertebrate classes from bony fish to human (Hatinen et al., 2007). However, not all vertebrate classes have all four orthologs of the respective growth factor ligands; although frogs have a GFR $\alpha 2$ receptor, an ortholog of NRTN is missing from the frog genome, and GDNF is thought to act as the endogenous ligand for both GFR $\alpha 1$ and GFR $\alpha 2$. The binding site of both GFR $\alpha 1$ and GFR $\alpha 2$ is similar in both frog and human (Hatinen et al., 2007), suggesting a mechanisms for the in vitro observations that both NRTN and GDNF can act via GFR $\alpha 1$ or GFR $\alpha 2$ (Baloh et al., 2000a; Airaksinen and Saarma, 2002). Further support for the functional overlap of GDNF and NRTN comes from the similarity in phenotype of mice overexpressing GDNF or NRTN in the skin: both GDNF-OE and NRTN-OE mice exhibited hypertrophy of nonpeptidergic endings and axons, and no change in response to noxious heat (Zwick et al., 2002). However, each growth factor appears to also have unique effects on polymodal nociceptor function; NRTN-OE but not GDNF-OE mice, expressed significant behavioral sensitivity to mechanical stimulation (Zwick et al., 2002), although an ex vivo, single-afferent analysis revealed a significant increase in mechanical sensitivity in GDNF-OE polymodal nociceptors (Albers et al., 2006). Moreover, TRPM8 is upregulated in NRTN-OE DRG, but downregulated in GDNF-OE mice (Albers et al., 2006). These results extend previous studies showing that development and maturation of individual populations of sensory afferents are the result of the combined effect of multiple neurotrophic growth factors, acting at various times during development (Molliver et al., 1997; Chen et al., 2006; Luo et al., 2007), each contributing differentially to the final afferent phenotype. Based on the extensive overlap of GFR $\alpha 1$ and GFR $\alpha 2$ expression in cutaneous afferents (Malin et al., 2011) and the demonstration that these neurons are initially dependent on NGF/TrkA signaling (Molliver et al., 1997), it seems reasonable to conclude that the phenotype of NRTN-responsive afferents is determined by the combination of growth factors and their receptors that are expressed at different times during development and that NRTN levels modulate cutaneous nociceptor functionality in the adult.

\section{References}

Abe J, Hosokawa H, Okazawa M, Kandachi M, Sawada Y, Yamanaka K, Matsumura K, Kobayashi S (2005) TRPM8 protein localization in trigeminal ganglion and taste papillae. Brain Res 136:91-98. CrossRef Medline

Airaksinen MS, Saarma M (2002) The GDNF family: signalling, biological functions and therapeutic value. Nat Rev Neurosci 3:383-394. CrossRef Medline

Albers KM, Wright DE, Davis BM (1994) Overexpression of nerve growth factor in epidermis of transgenic mice causes hypertrophy of the peripheral nervous system. J Neurosci 14:1422-1432. Medline
Albers KM, Perrone TN, Goodness TP, Jones ME, Green MA, Davis BM (1996) Cutaneous overexpression of NT-3 increases sensory and sympathetic neuron number and enhances touch dome and hair follicle innervation. J Cell Biol 134:487-497. CrossRef Medline

Albers KM, Woodbury CJ, Ritter AM, Davis BM, Koerber HR (2006) Glial cell-line-derived neurotrophic factor expression in skin alters the mechanical sensitivity of cutaneous nociceptors. J Neurosci 26:2981-2990. CrossRef Medline

Baloh RH, Tansey MG, Johnson EM Jr, Milbrandt J (2000a) Functional mapping of receptor specificity domains of glial cell line-derived neurotrophic factor (GDNF) family ligands and production of GFRalpha1 RET-specific agonists. J Biol Chem 275:3412-3420. CrossRef Medline

Baloh RH, Enomoto H, Johnson EM Jr, Milbrandt J (2000b) The GDNF family ligands and receptors: implications for neural development. Curr Opin Neurobiol 10:103-110. CrossRef Medline

Baudet C, Mikaels A, Westphal H, Johansen J, Johansen TE, Ernfors P (2000) Positive and negative interactions of GDNF, NTN and ART in developing sensory neuron subpopulations, and their collaboration with neurotrophins. Development 127:4335-4344. Medline

Bautista DM, Jordt SE, Nikai T, Tsuruda PR, Read AJ, Poblete J, Yamoah EN, Basbaum AI, Julius D (2006) TRPA1 mediates the inflammatory actions of environmental irritants and proalgesic agents. Cell 124:1269-1282. CrossRef Medline

Bautista DM, Siemens J, Glazer JM, Tsuruda PR, Basbaum AI, Stucky CL, Jordt SE, Julius D (2007) The menthol receptor TRPM8 is the principal detector of environmental cold. Nature 448:204-208. CrossRef Medline

Cao JP, Yu JK, Li C, Sun Y, Yuan HH, Wang HJ, Gao DS (2008) Integrin $\beta 1$ is involved in the signaling of glial cell line-derived neurotrophic factor. J Comp Neurol 509:203-210. CrossRef Medline

Chen CL, Broom DC, Liu Y, de Nooij JC, Li Z, Cen C, Samad OA, Jessell TM, Woolf CJ, Ma Q (2006) Runx1 determines nociceptive sensory neuron phenotype and is required for thermal and neuropathic pain. Neuron 49:365-377. CrossRef Medline

Chen J, Joshi SK, DiDomenico S, Perner RJ, Mikusa JP, Gauvin DM, Segreti JA, Han P, Zhang XF, Niforatos W, et al. (2011) Selective blockade of TRPA1 channel attenuates pathological pain without altering noxious cold sensation or body temperature regulation. Pain 152:1165-1172. CrossRef Medline

Colburn RW, Lubin ML, Stone DJ Jr, Wang Y, Lawrence D, D'Andrea MR, Brandt MR, Liu Y, Flores CM, Qin N (2007) Attenuated cold sensitivity in TRPM8 null mice. Neuron 54:379-386. CrossRef Medline

Coste B, Mathur J, Schmidt M, Earley TJ, Ranade S, Petrus MJ, Dubin AE, Patapoutian A (2010) Piezol and Piezo2 are essential components of distinct mechanically activated cation channels. Science 330:55-60. CrossRef Medline

da Costa DS, Meotti FC, Andrade EL, Leal PC, Motta EM, Calixto JB (2010) The involvement of the transient receptor potential A1 (TRPA1) in the maintenance of mechanical and cold hyperalgesia in persistent inflammation. Pain 148:431-437. CrossRef Medline

Davies A, Lumsden A (1984) Relation of target encounter and neuronal death to nerve growth factor responsiveness in the developing mouse trigeminal ganglion. J Comp Neurol 223:124-137. CrossRef Medline

del Camino D, Murphy S, Heiry M, Barrett LB, Earley TJ, Cook CA, Petrus MJ, Zhao M, D'Amours M, Deering N, Brenner GJ, Costigan M, Hayward NJ, Chong JA, Fanger CM, Woolf CJ, Patapoutian A, Moran MM (2010) TRPA1 contributes to cold hypersensitivity. J Neurosci 30:15165-15174. CrossRef Medline

Delcroix JD, Michael GJ, Priestley JV, Tomlinson DR, Fernyhough P (1998) Effect of nerve growth factor treatment on p75NTR gene expression in lumbar dorsal root ganglia of streptozocin-induced diabetic rats. Diabetes 47:1779-1785. CrossRef Medline

Dhaka A, Murray AN, Mathur J, Earley TJ, Petrus MJ, Patapoutian A (2007) TRPM8 is required for cold sensation in mice. Neuron 54:371-378. CrossRef Medline

Doran JF, Jackson P, Kynoch PA, Thompson RJ (1983) Isolation of PGP 9.5, a new human neurone-specific protein detected by high-resolution twodimensional electrophoresis. J Neurochem 40:1542-1547. CrossRef Medline

Elitt CM, McIlwrath SL, Lawson JJ, Malin SA, Molliver DC, Cornuet PK, Koerber HR, Davis BM, Albers KM (2006) Artemin overexpression in skin enhances expression of TRPV1 and TRPA1 in cutaneous sensory 
neurons and leads to behavioral sensitivity to heat and cold. J Neurosci 26:8578-8587. CrossRef Medline

Elitt CM, Malin SA, Koerber HR, Davis BM, Albers KM (2008) Overexpression of artemin in the tongue increases expression of TRPV1 and TRPA1 in trigeminal afferents and causes oral sensitivity to capsaicin and mustard oil. Brain Res 1230:80-90. CrossRef Medline

Fasanella KE, Christianson JA, Chanthaphavong RS, Davis BM (2008) Distribution and neurochemical identification of pancreatic afferents in the mouse. J Comp Neurol 509:42-52. CrossRef Medline

Forrest SL, Keast JR (2008) Expression of receptors for glial cell line-derived neurotrophic factor family ligands in sacral spinal cord reveals separate targets of pelvic afferent fibers. J Comp Neurol 506:989-1002. CrossRef Medline

Gratto KA, Verge VM (2003) Neurotrophin-3 down-regulates trkA mRNA, NGF high-affinity binding sites, and associated phenotype in adult DRG neurons. Eur J Neurosci 18:1535-1548. CrossRef Medline

Harrison SM, Jones ME, Uecker S, Albers KM, Kudrycki KE, Davis BM (2000) Levels of nerve growth factor and neurotrophin-3 are affected differentially by the presence of p75 in sympathetic neurons in vivo. J Comp Neurol 424:99-110. CrossRef Medline

Harrison SM, Davis BM, Nishimura M, Albers KM, Jones ME, Phillips HS (2004) Rescue of NGF-deficient mice: I. Transgenic expression of NGF in skin rescues mice lacking endogenous NGF. Brain Res 122:116-125. CrossRef Medline

Hätinen T, Holm L, Airaksinen MS (2007) Loss of neurturin in frog: comparative genomics study of GDNF family ligand-receptor pairs. Mol Cell Neurosci 34:155-167. CrossRef Medline

Heuckeroth RO, Enomoto H, Grider JR, Golden JP, Hanke JA, Jackman A, Molliver DC, Bardgett ME, Snider WD, Johnson EM Jr, Milbrandt J (1999) Gene targeting reveals a critical role for neurturin in the development and maintenance of enteric, sensory, and parasympathetic neurons. Neuron 22:253-263. CrossRef Medline

Holm S (1979) A simple sequentially rejective multiple test procedure. Scand J Statist 6:65-70.

Huang EJ, Reichardt LF (2001) Neurotrophins: roles in neuronal development and function. Annu Rev Neurosci 24:677-736. CrossRef Medline

Jankowski MP, Lawson JJ, McIlwrath SL, Rau KK, Anderson CE, Albers KM, Koerber HR (2009) Sensitization of cutaneous nociceptors after nerve transection and regeneration: possible role of target-derived neurotrophic factor signaling. J Neurosci 29:1636-1647. CrossRef Medline

Kobayashi K, Fukuoka T, Obata K, Yamanaka H, Dai Y, Tokunaga A, Noguchi K (2005) Distinct expression of TRPM8, TRPA1, and TRPV1 mRNAs in rat primary afferent neurons with $\mathrm{a} \delta / \mathrm{c}$-fibers and colocalization with trk receptors. J Comp Neurol 493:596-606. CrossRef Medline

Korsching S (1993) The neurotrophic factor concept: a reexamination. J Neurosci 13:2739-2748. Medline

Kotzbauer PT, Lampe PA, Heuckeroth RO, Golden JP, Creedon DJ, Johnson EM Jr, Milbrandt J (1996) Neurturin, a relative of glial-cell-line-derived neurotrophic factor. Nature 384:467-470. CrossRef Medline

Lewin GR, Barde YA (1996) Physiology of the neurotrophins. Annu Rev Neurosci 19:289-317. CrossRef Medline

Li L, Rutlin M, Abraira VE, Cassidy C, Kus L, Gong S, Jankowski MP, Luo W, Heintz N, Koerber HR, Woodbury CJ, Ginty DD (2011) The functional organization of cutaneous low-threshold mechanosensory neurons. Cell 147:1615-1627. CrossRef Medline

Lindfors PH, Võikar V, Rossi J, Airaksinen MS (2006) Deficient nonpeptidergic epidermis innervation and reduced inflammatory pain in glial cell line-derived neurotrophic factor family receptor alpha2 knock-out mice. J Neurosci 26:1953-1960. CrossRef Medline

Lu J, Zhou XF, Rush RA (2001) Small primary sensory neurons innervating epidermis and viscera display differential phenotype in the adult rat. Neurosci Res 41:355-363. CrossRef Medline

Luo W, Wickramasinghe SR, Savitt JM, Griffin JW, Dawson TM, Ginty DD (2007) A hierarchical NGF signaling cascade controls Ret-dependent and Ret-independent events during development of nonpeptidergic DRG neurons. Neuron 54:739-754. CrossRef Medline

Luo W, Enomoto H, Rice FL, Milbrandt J, Ginty DD (2009) Molecularidentification of rapidly adapting mechanoreceptors and their developmental dependence on ret signaling. Neuron 64:841-856. CrossRef Medline

Malin SA, Molliver DC, Koerber HR, Cornuet P, Frye R, Albers KM, Davis BM (2006) Glial cell line-derived neurotrophic factor family members sensitize nociceptors in vitro and produce thermal hyperalgesia in vivo. J Neurosci 26:8588-8599. CrossRef Medline

Malin SA, Davis BM, Molliver DC (2007) Production of dissociated sensory neuron cultures and considerations for their use in studying neuronal function and plasticity. Nat Protoc 2:152-160. CrossRef Medline

Malin S, Molliver D, Christianson JA, Schwartz ES, Cornuet P, Albers KM, Davis BM (2011) TRPV1 and TRPAl function and modulation are target tissue dependent. J Neurosci 31:10516-10528. CrossRef Medline

McAllister AK, Katz LC, Lo DC (1999) Neurotrophins and synaptic plasticity. Annu Rev Neurosci 22:295-318. CrossRef Medline

McKemy DD, Neuhausser WM, Julius D (2002) Identification of a cold receptor reveals a general role for TRP channels in thermosensation. Nature 416:52-58. CrossRef Medline

Mendell LM, Albers KM, Davis BM (1999) Neurotrophins, nociceptors, and pain. Microsc Res Tech 45:252-261. CrossRef Medline

Mogil JS, Adhikari SM (1999) Hot and cold nociception are genetically correlated. J Neurosci 19:RC25. Medline

Molliver DC, Wright DE, Leitner ML, Parsadanian AS, Doster K, Wen D, Yan Q, Snider WD (1997) IB4-binding DRG neurons switch from NGF to GDNF dependence in early postnatal life. Neuron 19:849-861. CrossRef Medline

Nosrat CA (1998) Neurotrophic factors in the tongue: expression patterns, biological activity, relation to innervation and studies of neurotrophin knockout mice. Ann N Y Acad Sci 855:28-49. CrossRef Medline

Paratcha G, Ledda F, Ibáñez CF (2003) The neural cell adhesion molecule NCAM is an alternative signaling receptor for GDNF family ligands. Cell 113:867-879. CrossRef Medline

Peier AM, Moqrich A, Hergarden AC, Reeve AJ, Andersson DA, Story GM, Earley TJ, Dragoni I, McIntyre P, Bevan S, Patapoutian A (2002) A TRP channel that senses cold stimuli and menthol. Cell 108:705-715. CrossRef Medline

Poteryaev D, Titievsky A, Sun YF, Thomas-Crusells J, Lindahl M, Billaud M, Arumäe U, Saarma M (1999) GDNF triggers a novel ret-independent Src kinase family-coupled signaling via a GPI-linked GDNF receptor $\alpha 1$. FEBS Lett 463:63-66. CrossRef Medline

Price MP, Lewin GR, McIlwrath SL, Cheng C, Xie J, Heppenstall PA, Stucky CL, Mannsfeldt AG, Brennan TJ, Drummond HA, Qiao J, Benson CJ, Tarr DE, Hrstka RF, Yang B, Williamson RA, Welsh MJ (2000) The mammalian sodium channel BNC1 is required for normal touch sensation. Nature 407:1007-1011. CrossRef Medline

Rossi J, Luukko K, Poteryaev D, Laurikainen A, Sun YF, Laakso T, Eerikäinen S, Tuominen R, Lakso M, Rauvala H, Arumäe U, Pasternack M, Saarma M, Airaksinen MS (1999) Retarded growth and deficits in the enteric and parasympathetic nervous system in mice lacking GFR $\alpha 2$, a functional neurturin receptor. Neuron 22:243-252. CrossRef Medline

Schmutzler BS, Roy S, Pittman SK, Meadows RM, Hingtgen CM (2011) Ret-dependent and Ret-independent mechanisms of Gfl-induced sensitization. Mol Pain 7:22. CrossRef Medline

Schwartz ES, Lee I, Chung K, Chung JM (2008) Oxidative stress in the spinal cord is an important contributor in capsaicin-induced mechanical secondary hyperalgesia in mice. Pain 138:514-524. CrossRef Medline

Schwartz ES, Christianson JA, Chen X, La JH, Davis BM, Albers KM, Gebhart GF (2011) Synergistic role of TRPV1 and TRPA1 in pancreatic pain and inflammation. Gastroenterology 140:1283-1291. CrossRef Medline

Snider WD, McMahon SB (1998) Tackling pain at the source: new ideas about nociceptors. Neuron 20:629-632. CrossRef Medline

Stucky CL, Lewin GR (1999) Isolectin B(4)-positive and-negative nociceptors are functionally distinct. J Neurosci 19:6497-6505. Medline

Stucky CL, Rossi J, Airaksinen MS, Lewin GR (2002) GFR $\alpha 2 /$ neurturin signalling regulates noxious heat transduction in isolectin B4-binding mouse sensory neurons. J Physiol 545:43-50. CrossRef Medline

Suzuki SC, Furue H, Koga K, Jiang N, Nohmi M, Shimazaki Y, Katoh-Fukui Y, Yokoyama M, Yoshimura M, Takeichi M (2007) Cadherin-8 is required for the first relay synapses to receive functional inputs from primary sensory afferents for cold sensation. J Neurosci 27:3466-3476. CrossRef Medline

Takashima Y, Ma L, McKemy DD (2010) The development of peripheral cold neural circuits based on TRPM8 expression. Neuroscience 169:828842. CrossRef Medline

Võikar V, Rossi J, Rauvala H, Airaksinen MS (2004) Impaired behavioural flexibility and memory in mice lacking GDNF family receptor alpha2. Eur J Neurosci 20:308-312. CrossRef Medline 
Wang T, Molliver DC, Jing X, Schwartz ES, Yang FC, Samad OA, Ma Q, Davis BM (2012) Phenotypic switching of nonpeptidergic cutaneous sensory neurons following peripheral nerve injury. PloS One 6:e28908. CrossRef Medline

Wanigasekara Y, Keast JR (2006) Nerve growth factor, glial cell line-derived neurotrophic factor and neurturin prevent semaphorin 3A-mediated growth cone collapse in adult sensory neurons. Neuroscience 142:369379. CrossRef Medline
Woodbury CJ, Zwick M, Wang S, Lawson JJ, Caterina MJ, Koltzenburg M, Albers KM, Koerber HR, Davis BM (2004) Nociceptors lacking TRPV1 and TRPV2 have normal heat responses. J Neurosci 24:6410-6415. CrossRef Medline

Zwick M, Davis BM, Woodbury CJ, Burkett JN, Koerber HR, Simpson JF, Albers KM (2002) Glial cell line-derived neurotrophic factor is a survival factor for isolectin B4-positive, but not vanilloid receptor 1-positive, neurons in the mouse. J Neurosci 22:4057-4065. Medline 